IWONA CHRZANOWSKA

Społeczna Akademia Nauk, Łódź,

Wydział Studiów Edukacyjnych

Uniwersytet im. Adama Mickiewicz

Poznań
Forum Pedagogiczne $2016 / 1$

Wpłynęło: 27.11.2015

Zatwierdzono do druku: 03.03.2016

\title{
STAN I ROZMIARY UDZIAŁU DZIECI I MŁODZIEŻY Z NIEPEŁNOSPRAWNOŚCIĄ W EDUKACJI WŁĄCZAJĄCEJ W POLSCE
}

Streszczenie: Edukacja włączająca osoby z niepełnosprawnością jest współczesną tendencją kształcenia w Polsce. W 2012 r. Polska ratyfikowała Konwencję o prawach osób niepetnosprawnych. Tekst ten podejmuje próbę analizy realizacji idei w odniesieniu do wszystkich etapów obowiązkowej edukacji. Jest również próbą zdiagnozowania głównych barier, które to utrudniają.

Słowa kluczowe: edukacja włączająca, niepełnosprawność, bariery

\section{Wprowadzenie}

Rozważania dotyczące problematyki oświatowej i kształcenia osób z niepełnosprawnością zostały w ostatnich latach zdominowane właściwie przez jeden termin: „edukacja włączająca”. Szczególną popularność zawdzięcza on zapisom przyjętej przez ONZ w 2006 r. Konwencji o prawach osób niepetnosprawnych, ratyfikowanej przez Polskę w październiku 2012 r., a zwłaszcza treści art. 24. W art. 24. pkt 1 Konwencji uznaje się prawo osób z niepełnosprawnością do edukacji bez dyskryminacji i na zasadzie równych szans. Na mocy dokumentu państwa mają zapewnić włączający system kształcenia, umożliwiający integrację na wszystkich poziomach edukacji i w kształceniu ustawicznym (Konwencja... 2012) ${ }^{1}$. Przynajmniej zatem od dekady w środowisku teoretyków i praktyków edukacji osób z niepełnosprawnością trwają dyskusje o tym, jak należy rozumieć termin „edukacja włączająca”. Czy jest to synonim integracji edukacyjnej, czy może kolejny jej etap, doskonalsza, bardziej rozwinięta forma, która jako jedno z rozwiązań kształcenia osób

\footnotetext{
1 Konwencja o prawach osób niepełnosprawnych została podpisana w Nowym Jorku 13 grudnia 2006 r., Polska przyjęła ją jednak dopiero sześć lat później. Wynikało to m.in. z konieczności dostosowania prawa wewnętrznego i stworzenia warunków do jej realizacji. Można zatem uznać, że od 2012 r. istnieją w przekonaniu władz w Polsce warunki do jej respektowania.
} 
z niepełnosprawnością realizowana jest w Polsce od połowy lat 9o. XX w., a może jest to nowa jakość, nowe, nieobecne dotąd rozwiązanie?

Kluczowa w rozstrzygnięciu tej kwestii wydaje się przyjęta płaszczyzna rozważań. Szeroka społeczna perspektywa pozwala traktować pojęcia włączania i integracji synonimicznie, zwłaszcza w odniesieniu do celu i skutku podejmowanych inicjatyw. W obu bowiem przypadkach istotą jest równe traktowanie, tożsamość praw, jedność bez kategoryzowania, sprzeciw wobec selekcji, zwłaszcza koncentrującej się na deficytach, wobec podkreślania nie tego, co łączy, a tego, co dzieli. Takiemu podejściu przyświecają również idee dostrzegające racjonalność i nieuchronność odmienności, odnajdywania w niej waloru, a nie przeszkody dla wspólnej bezkonfliktowej koegzystencji. Perspektywa węższa, ograniczona np. do systemowych działań edukacyjnych, skłania do rozgraniczania pojęć. Choćby $\mathrm{w}$ dokumentach formalnoprawnych czym innym jest klasa/oddział integracyjny, a czym innym klasa/szkoła włączająca. Drugie określenie skłoniło wielu teoretyków, praktyków i pracowników instytucji (w tym rządowych) do poszukiwania różnic między pojęciami, uzasadnionych m.in. chronologią działań i decyzji. W ten sposób kształcenie w głównym nurcie uznane zostało przez wielu za konsekwencję i kolejny etap działań systemowych, bardziej zaawansowaną formę integracji (Chrzanowska 2015, s. 34). Wątpliwości wydaje się nie budzić fakt, że zarówno integracja, jak i włączanie mają tę samą podstawę filozoficzną, której istotą są prawa człowieka utożsamiane z prawami naturalnymi przysługującymi wszystkim ludziom. Oznacza to, że ludzi nie można różnicować z jakichkolwiek względów i w związku z tym przypisywać im różnych katalogów praw. Podobnie nie sposób zaprzeczać temu, że przeniesienie tej idei na grunt praktyki oświatowej w Polsce zaowocowało dwoma wariantami rozwiązań edukacyjnych, dwoma formami kształcenia: integracyjną i włączającą. Różnią się one głównie warunkami organizacyjnymi kształcenia (dotyczącymi m.in. liczebności uczniów w klasie, proporcji uczniów z niepełnosprawnością do uczniów sprawnych, doświadczeń współpracy pedagogów i pedagogów specjalnych). Tytułowe rozważania prowadzone będą z uwzględnieniem praktycznych rozwiązań różniących kształcenie integracyjne od edukacji włączającej. Odnoszone one będą również do postanowień ratyfikowanej przez Polskę Konwencji, zwłaszcza tych, które koncentrują się na udziale dzieci i młodzieży z niepełnosprawnością w edukacji włączającej.

\section{Edukacja włączająca osoby z niepełnosprawnością - od etapu edukacji przedszkolnej po gimnazjum}

Na mocy Konwencji zagwarantowano, że:

„(a) osoby niepełnosprawne nie będą wykluczone z powszechnego systemu edukacji ze względu na niepełnosprawność, a także, że dzieci niepełnosprawne nie będą wykluczone z bezpłatnej i obowiązkowej nauki w szkole podstawowej lub z nauczania na poziomie średnim, 
(b) osoby niepełnosprawne będą korzystać z włączającego, bezpłatnego nauczania obowiązkowego wysokiej jakości, na poziomie podstawowym i średnim na zasadzie równości z innymi osobami, w społecznościach, w których żyją,

(c) wprowadzone będą racjonalne usprawnienia, zgodne $\mathrm{z}$ indywidualnymi potrzebami,

(d) osoby niepełnosprawne będą uzyskiwać niezbędne wsparcie, w ramach powszechnego systemu edukacji, celem ułatwienia ich skutecznej edukacji,

(e) stosowane będą skuteczne środki zindywidualizowanego wsparcia w środowisku, które maksymalizuje rozwój edukacyjny i społeczny zgodnie z celem pełnego włączenia” (art. 24 pkt 2, Konwencja... 2012, s. 13).

Warto przyjrzeć się temu, jak przedstawia się realizacja gwarancji zapisanych w Konwencji. Z danych raportu IBE (Grzelak i in. 2014) wynika, że 75\% dzieci z niepełnosprawnością uczestniczy w edukacji przedszkolnej. Jest to wskaźnik niemal identyczny jak w przypadku populacji ogólnej (75,4\%) (Falkowska, Telusiewicz-Pacak 2013, s. 14). Podobnie jak w populacji ogólnej widoczne jest zróżnicowanie udziału dzieci z niepełnosprawnością w edukacji przedszkolnej związane z miejscem ich zamieszkania. Najwięcej ich uczęszcza do przedszkoli w aglomeracjach miejskich i w dużych miastach.

Rysunek 1. Dziecko z niepełnosprawnością w edukacji przedszkolnej a miejsce zamieszkania (źródło: Grzelak i in. 2014, s. 38)

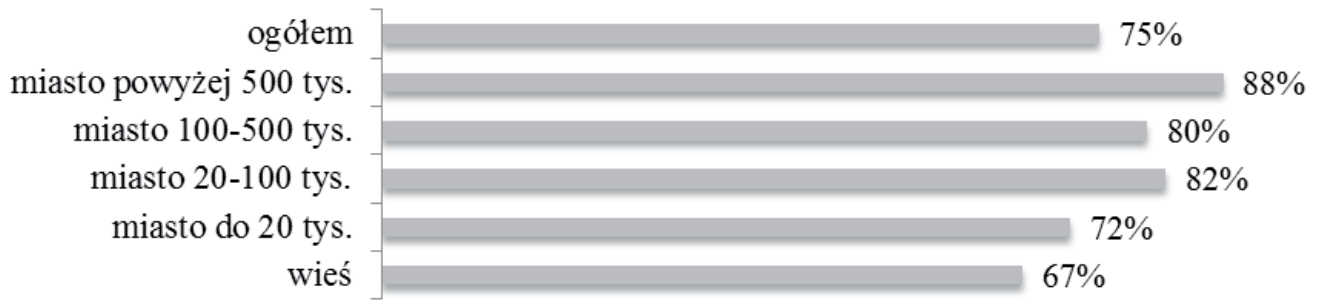

Jak pokazują analizy, edukacja przedszkolna dzieci z niepełnosprawnością powiązana jest z poziomem wykształcenia rodziców. Im wyższe wykształcenie rodziców, tym wyższe wskaźniki uczestnictwa dzieci w edukacji przedszkolnej.

Rysunek 2. Udział dzieci z niepełnosprawnością w edukacji przedszkolnej a wykształcenie rodziców (źródło: Grzelak i in. 2014, s. 41)

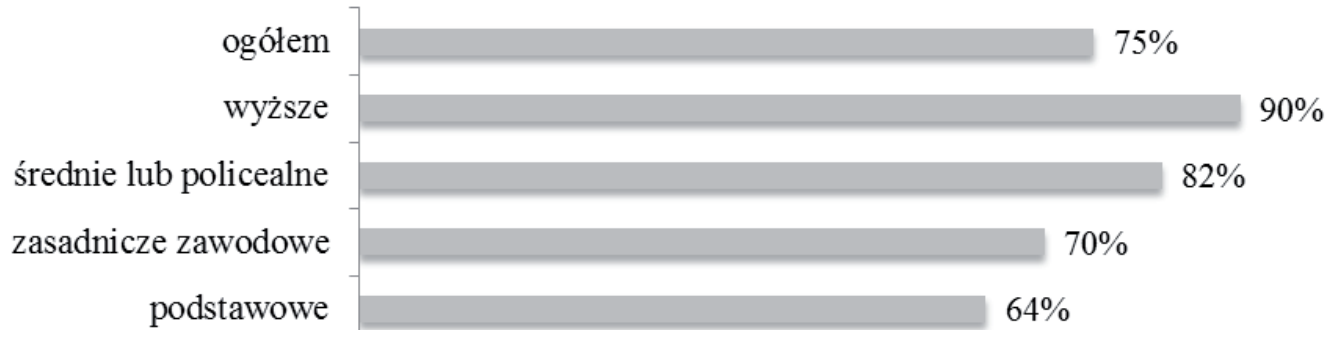


Zróżnicowanie udziału najmłodszych dzieci w edukacji instytucjonalnej warunkowane jest także rodzajem niepełnosprawności. Najczęściej niepełnosprawnym przedszkolakiem jest dziecko z ASD, najrzadziej - niewidzące.

Rysunek 3. Udział w edukacji przedszkolnej a rodzaj niepełnosprawności (źródło: Grzelak i in. 2014, s. 39)

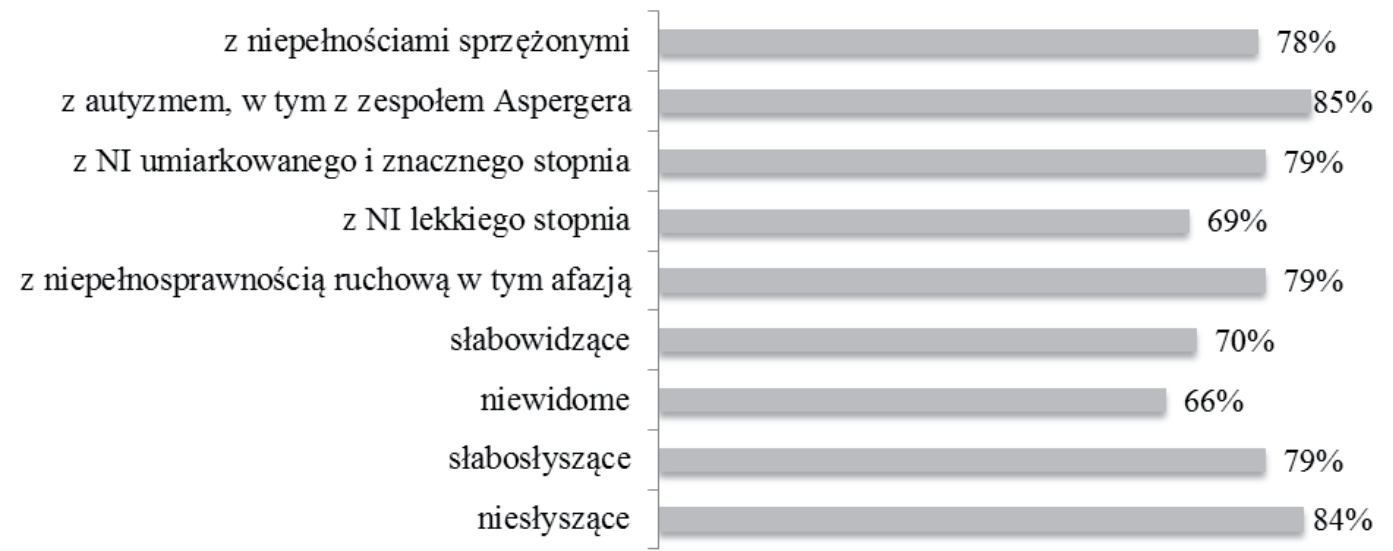

Zdecydowana większość dzieci z niepełnosprawnością uczęszcza do przedszkoli włączających. Jak wskazują wyniki badań w placówkach publicznych, 79,1\% zapisanych jest do przedszkoli ogólnodostępnych, 17,2\% do integracyjnych i tylko 3,8\% do specjalnych. Nieco inaczej wskaźniki przedstawiają się w przypadku placówek niepublicznych. Niższe są wartości procentowe udziału dzieci z niepełnosprawnością w edukacji wspólnie z pełnosprawnymi rówieśnikami $(65,4 \%$ - szkoły ogólnodostępne i $25,9 \%$ - integracyjne), a wyższe w szkołach specjalnych $(8,6 \%)$ (Falkowska, Telusiewicz-Pacak 2013, s. 41).

Zróżnicowanie wyborów w odniesieniu do placówek publicznych i niepublicznych skłania do refleksji, szczególnie w przypadku przedszkoli specjalnych. Można, jak się wydaje, postawić tezę, że rodzice dzieci z niepełnosprawnością wciąż oczekują zróżnicowanej oferty edukacyjnej, w której jest możliwość wyboru między przedszkolem włączającym, integracyjnym i specjalnym. Przemawiają za tym relatywnie wysokie wskaźniki korzystania z niepublicznych przedszkoli specjalnych jako miejsc wczesnej edukacji dziecka z niepełnosprawnością. Nie wydaje się, że oznacza to sprzeciw wobec edukacji włączającej (wskaźniki udziału we włączających formach edukacji przedszkolnej są wielokrotnie wyższe niż specjalnej, również w przypadku placówek niepublicznych). To bardziej przejaw oceny jakości i stopnia zaawansowania działań włączających. Tak długo bowiem, jak rodzice dzieci z niepełnosprawnością będą spotykali się z odmową przyjęcia ich dziecka do przedszkola ogólnodostępnego i będą zmuszeni przenosić je w trakcie edukacji z przedszkola ogólnodostępnego do specjalnego z uwagi na brak postępów, 
dostrzegany brak wsparcia czy kompetencji kadry w pracy z dzieckiem (Grzelak i in. 2014), wielość form edukacji i obecność oferty kształcenia specjalnego na etapie przedszkola będą przez rodziców oczekiwane, pożądane i uzasadnione.

$\mathrm{Na}$ etapie szkoły podstawowej mniej więcej od połowy lat 9o. XX w. obserwowany jest wzrost udziału uczniów z niepełnosprawnością w edukacji włączającej. Początkowo, z oczywistych względów ${ }^{2}$, dzieci zamieniały szkoły specjalne głównie na placówki integracyjne, dopiero od połowy pierwszej dekady XXI w. coraz częściej można było spotkać ucznia z niepełnosprawnością w placówce ogólnodostępnej $^{3}$. Od roku 1990/1991 do roku 2012/2013 obserwowana jest zmiana preferencji kształcenia uczniów z niepełnosprawnością na etapie szkoły podstawowej. Po początkowej dominacji edukacji specjalnej nastąpiło względne wyrównanie udziału każdej z form ${ }^{4}$. Współcześnie w szkołach specjalnych kształci się około 40\% uczniów z niepełnosprawnością, w kształceniu integracyjnym (w rozumieniu rozporządzenia z 1993 r.) - około 24\%, a w edukacji włączającej - około 35\% (Chrzanowska 2015, s. 567). Odnosząc te wskaźniki do zaprezentowanych na początku postanowień Konwencji, należy zauważyć, że w dalszym ciągu w Polsce nie zostały jeszcze stworzone warunki umożliwiające włączenie wszystkich uczniów z niepełnosprawnością w nurt kształcenia ogólnodostępnego. Wciąż 40\% kształci się w placówkach specjalnych. Choć trudno jest znaleźć wyniki badań odpowiadające wprost na pytanie o przyczyny takiego stanu rzeczy, $z$ danych prezentowanych w różnorodnych raportach można wyciągnąć wnioski wskazujące na: brak przygotowania placówek ogólnodostępnych do przyjęcia i kształcenia uczniów, zwłaszcza z głębszymi stopniami niepełnosprawności czy z niepełnosprawnościami sprzężonymi; braki w zakresie specjalistycznej kadry szkół ogólnodostępnych i/ lub kompetencji dotyczących postępowania z niepełnosprawnościami (w tym dydaktyczno-wychowawczych umiejętności pracy w grupie zróżnicowanej); istnienie postaw społecznych, które nie sprzyjają akceptacji obecności osób z niepełnosprawnością w klasie szkolnej, ujawnianych zarówno przez pedagogów lub sprawnych rówieśników, jak i rodziców. Nie zawsze też rodzice dążą do umieszczenia dziecka z niepełnosprawnością w placówce integracyjnej czy ogólnodostępnej. Bywa, że dopiero na etapie kształcenia w szkole podstawowej zmieniają zadanie i po kilku

2 W 1993 r. formalnie wprowadzono w Polsce jako formę kształcenia klasę/szkołę integracyjną (Zarządzenie nr 29 MEN z dn. 4 października 1993 r. w sprawie zasad organizowania opieki nad uczniami niepetnosprawnymi, ich kształcenia w ogólnodostępnych i integracyjnych publicznych przedszkolach, szkołach i placówkach organizacji kształcenia specjalnego).

3 W 2005 r. pojawiło się rozporządzenie MENiS umożliwiające przyjęcie dziecka z niepełnosprawnością do placówki ogólnodostępnej (Rozporządzenie MENiS z dn. 18 stycznia 2005 r. w sprawie warunków organizowania kształcenia, wychowania i opieki dzieci i młodzieży niepełnosprawnych oraz niedostosowanych społecznie w przedszkolach, szkołach i oddziałach ogólnodostępnych i integracyjnych).

4 Szczegółowe analizy prezentowane są w publikacji Pedagogika specjalna. Od tradycji do współczesności (Chrzanowska 2015, s. 566). 
latach doświadczeń edukacyjnych w szkole ogólnodostępnej decydują się na przeniesienie go do placówki specjalnej. Ma to miejsce zazwyczaj wówczas, gdy nie zostały spełnione ich oczekiwania w zakresie warunków kształcenia, organizacji, wsparcia udzielanego dziecku czy klimatu społecznego placówki włączającej.

Przyglądając się grupie uczniów z niepełnosprawnością, uczestniczącej w edukacji inkluzyjnej na etapie szkoły podstawowej, można zauważyć, że najczęściej w klasie zwykłej szkoły ogólnodostępnej i w klasie integracyjnej spotkać można dzieci: z niepełnosprawnością ruchową, słabosłyszące, słabowidzące, z ASD i przewlekle chore. Znacznie rzadziej zaś z niepełnosprawnością intelektualną (niezależnie od jej stopnia), niepełnosprawnościami sprzężonymi oraz głębszymi stopniami niepełnosprawności sensorycznych.

Rysunek 4. Rodzaj niepełnosprawności a udział w edukacji włączającej - szkoła podstawowa (opracowanie własne na podstawie: Uczniowie i studenci niepełnosprawni...)

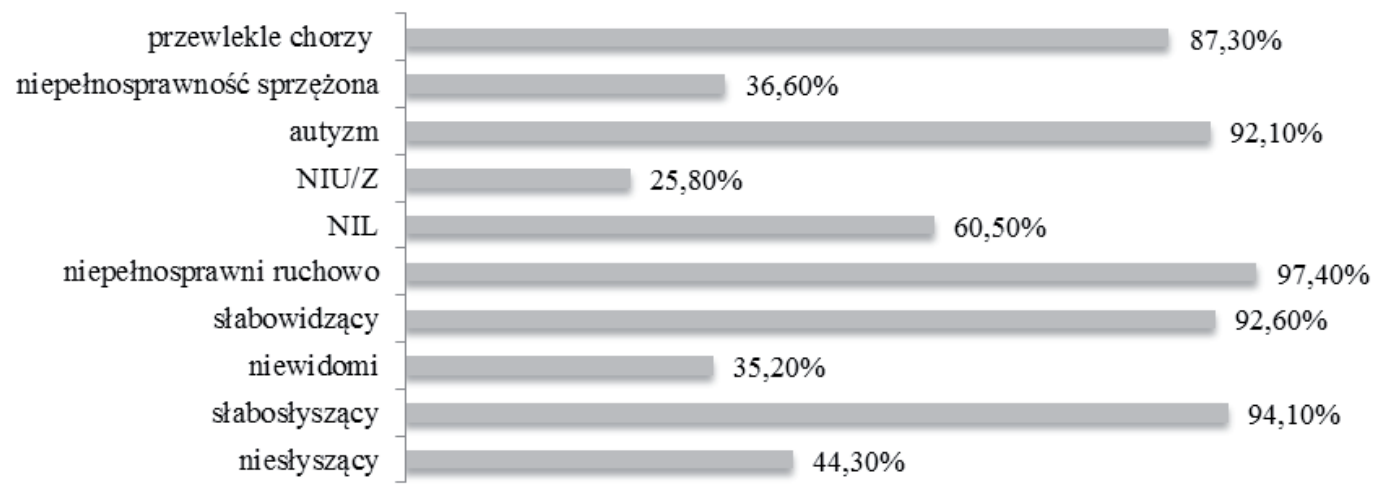

Wyniki współczesnych analiz pokazują, że mimo upływu lat i zakładanego wzrostu doświadczeń w zakresie kształcenia dzieci i młodzieży z niepełnosprawnością w realiach edukacyjnych tej grupy uczniów w zasadzie niewiele się zmienia. Wciąż, podobnie jak kilka dekad temu, w szkołach ogólnodostępnych zazwyczaj znajdują się uczniowie z niepełnosprawnością lżejszego stopnia i nieujawniający zaburzeń w sferze intelektualnej (Pańczyk 2001, s. 96).

$\mathrm{Na}$ etapie gimnazjum tendencje zaobserwowane w przypadku szkoły podstawowej się utrzymują. Z kształcenia w ramach edukacji włączającej korzystają najczęściej uczniowie: z niepełnosprawnością ruchową, słabosłyszący, słabowidzący, z ASD i przewlekle chorzy ${ }^{5}$. Przy czym w odróżnieniu od szkoły podstawowej na pierwszym miejscu wśród realizujących kształcenie w edukacji włączającej są uczniowie z ASD.

${ }^{5}$ Słowo „najczęściej” nie oznacza, że uczniów z tych grup jest w szkołach ogólnodostępnych i integracyjnych najwięcej w sensie liczebności, chodzi tu o proporcje do liczby uczniów z danym rodzajem niepełnosprawności w ogóle. 
Rysunek 5. Rodzaj niepełnosprawności a udział w edukacji włączającej - gimnazjum (opracowanie własne na podstawie: Uczniowie i studenci niepełnosprawni...)

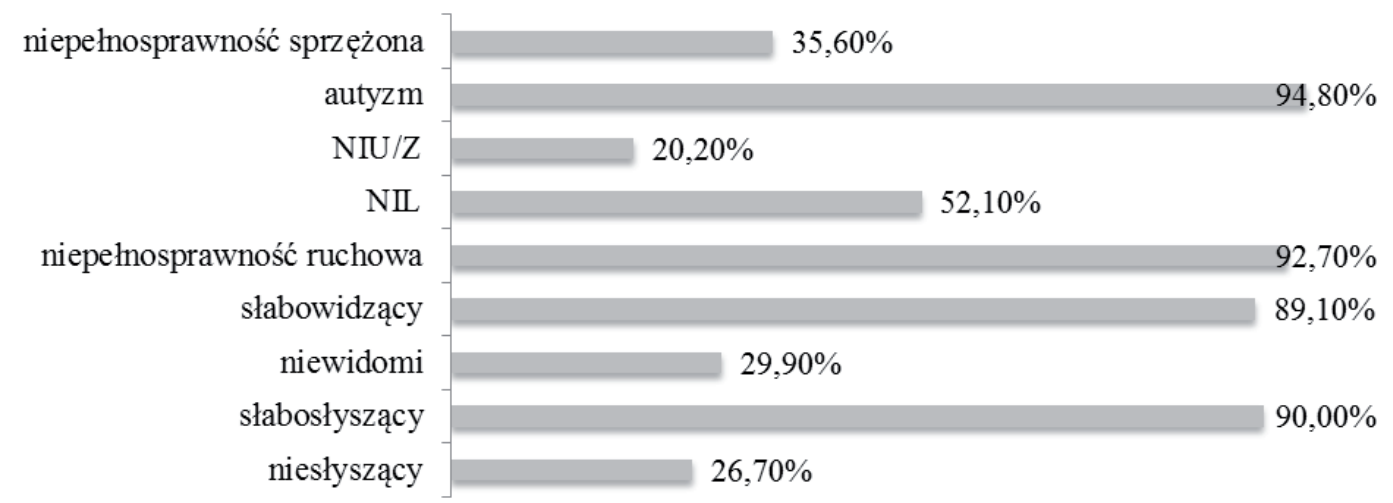

W kolejnych etapach edukacji włączającej uczestniczy coraz większa grupa dzieci z ASD. Na etapie przedszkola ich wskaźnik wynosi $85 \%$, szkoły podstawowej-92,1\%, a gimnazjum - 94,8\%. W przypadku żadnej innej grupy uczniów nie zaobserwowano takiej tendencji. W większości przypadków, po wzroście liczby uczniów w placówkach ogólnodostępnych i integracyjnych między etapem kształcenia przedszkolnego i podstawowego, na poziomie gimnazjum następował w tym zakresie spadek. Sugeruje to, że placówki ogólnodostępne, jak również w jakiejś mierze integracyjne, nie są w stanie przyjąć osób z niepełnosprawnością i zapewnić im kształcenia zakończonego sukcesem. Warto również zaznaczyć, że placówek/ klas/oddziałów integracyjnych, w których w odróżnieniu od zwykłych klas w szkołach ogólnodostępnych istnieją określone w rozporządzeniu MEN z 1993 r. warunki (m.in. ograniczona liczba uczniów w klasie z określoną minimalną i maksymalną liczbą uczniów z niepełnosprawnością, podwójna obsada pedagogiczna itp.), chętnych jest więcej niż miejsc. Oznacza to, że sieć placówek tego typu w Polsce jest wciąż niewystarczająca.

Teoretycznie zgodnie z wizją MEN zmiany, wprowadzone m.in. przez przyjęcie Konwencji, miały zapewnić w szkołach ogólnodostępnych warunki do efektywnego kształcenia (w tym nauczania-uczenia się i wychowania) uczniom z niepełnosprawnością. W rzeczywistości jednak, jak pokazują dane, tak nie jest, a uczniowie $\mathrm{z}$ niepełnosprawnością wciąż jeszcze mają problemy nie tylko z przyjęciem ich do szkoły ogólnodostępnej i pozostaniem w niej w ramach jednego poziomu, ale także, nawet większe, z przechodzeniem w ramach tej samej formy kształcenia do kolejnych etapów edukacyjnych ${ }^{6}$.

${ }^{6}$ Często jest tak, że uczniowie rozpoczynają kształcenie np. w placówce ogólnodostępnej w klasie zwykłej, ale w trakcie edukacji są przenoszeni do szkół specjalnych (czasami w efekcie samodzielnej decyzji rodziców - z uwagi na niezadowalającą ocenę wsparcia udzielanego dziecku, 
Znacznie trudniejsza jest w tym przypadku sytuacja uczniów, którzy od początku edukacji w dużo mniejszym stopniu uczestniczyli w edukacji wspólnej ze sprawnymi rówieśnikami. Do grupy tej należą osoby: z niepełnosprawnością intelektualną, niepełnosprawnością sprzężoną oraz głębszymi stopniami niepełnosprawności (na poziomie umiarkowanym, znacznym czy głębokim), np. uszkodzeniem wzroku czy słuchu. Niewielkie wskaźniki ich uczestnictwa w edukacji włączającej na wszystkich etapach kształcenia, z gimnazjum włącznie, wskazują, że realizacja postanowień Konwencji w dosłownym ich rozumieniu wciąż jest w Polsce bardziej możliwością niż faktem.

Warto bowiem przypomnieć, że na mocy art. 24. pkt 2b Konwencji „osoby niepełnosprawne będą korzystać z włączającego, bezpłatnego nauczania obowiązkowego wysokiej jakości, na poziomie podstawowym i średnim na zasadzie równości z innymi osobami, w społecznościach, w których żyją". Zobowiązanie to nie wyklucza żadnej grupy osób z niepełnosprawnością z edukacji włączającej. Przyjąć zatem należy, że mają do niej prawo również osoby z głębszą (umiarkowaną, znaczną) i głęboką lub sprzężoną niepełnosprawnością.

Zdaniem wielu specjalistów zajmujących się problematyką edukacji włączającej (tak teoretyków, jak i praktyków) w Polsce nie ma jeszcze z jednej strony warunków ${ }^{7}$ do skutecznego kształcenia w szkołach ogólnodostępnych, zwłaszcza uczniów z głębszymi (wyższymi niż lekki) stopniami niepełnosprawności czy

jego sukcesów, wykorzystania potencjału, kompetencji kadry pedagogicznej, lub za namową specjalistów; decyzję o zmianie placówki podejmują także sami uczniowie ze względu na poczucie osamotnienia, wykluczenia, stygmatyzacji). Innym problemem jest w tym przypadku wciąż niewydolny system orzekania o niepełnosprawności w Polsce. Decyzje wraz z zaleceniami wydawane są czasami po kilku latach od rozpoczęcia edukacji. W przypadku osób z niepełnosprawnością intelektualną lekkiego stopnia 12\% uzyskuje diagnozę w wieku 8 lat, $8 \%$ - 9 lat, $10 \%$ - 10 lat, 8\% - 11 lat, 5\% w wieku 12-16 lat. Wśród dzieci z ASD 13\% zdiagnozowanych jest w wieku 6 lat, a $38 \%$ w wieku od 7. do 15. roku życia (Grzelak i in. 2014, s. 34).

$7 \mathrm{~W}$ wielu polskich szkołach nie usunięto barier architektonicznych, zaliczanych do kategorii podstawowych w kontekście fizycznej dostępności. Nawet jeśli zmiany są widoczne na zewnątrz budynków (podjazdy), to wewnątrz wciąż znajdują się schody, brakuje wind, toalet dla osób z niepełnosprawnością, dostosowanych sal dydaktycznych itp. Do kategorii barier podstawowych należy też wciąż niewielka w polskim społeczeństwie wiedza na temat niepełnosprawności, możliwości i funkcjonowania osób z niepełnosprawnością. Często jest ona oparta na stereotypach, uprzedzeniach, a w efekcie stygmatyzująca i naznaczająca. Głównym problemem jest jednak mentalność, czyli przyjmowane postawy społeczne. Wciąż jeszcze w wielu szkołach ogólnodostępnych nauczyciele nie wyobrażają sobie współpracy w klasie szkolnej z uczniem z lekką niepełnosprawnością, twierdzą, że nie posiadają do tego wystarczających kwalifikacji. Niepełnosprawności sprzężone czy cięższego stopnia powodują zwielokrotnienie ich obaw, graniczące $z$ wykluczeniem takiej ewentualności. Problemem są również postawy i nastawienia rodziców dzieci sprawnych, którzy - zresztą podobnie jak część nauczycieli - traktują ucznia z niepełnosprawnością w kategorii obciążenia utrudniającego edukację uczniów sprawnych. Znaczna część dzieci i młodzieży z niepełnosprawnością jest izolowana i odrzucana przez rówieśników. 
niepełnosprawnościami sprzężonymi, z drugiej zaś strony, specjaliści, ale także część rodziców dzieci z niepełnosprawnością uznają, że dosłowna realizacja postanowień przyjętej Konwencji jest dyskusyjna. Podnoszona jest kwestia prawa do wolności, w tym wyboru drogi kształcenia ${ }^{8}$, co w zasadzie będzie możliwe tylko wówczas, gdy oferta edukacyjna będzie zróżnicowana. Jest to ważne szczególnie na początkowym etapie wprowadzania edukacji włączającej, z czym mamy do czynienia w Polsce. Tak długo jak w zwykłej klasie każdej szkoły ogólnodostępnej nie będą zapewnione warunki dla każdego ucznia z niepełnosprawnością, i to satysfakcjonujące uczniów oraz ich rodziców, powinny istnieć różne alternatywne formy organizacyjne kształcenia. Trudno się bowiem zgodzić na eksperymentowanie na dziecku, uczenie się pracy z dzieckiem z niepełnosprawnością metodą prób i błędów. Zawsze do pewnego stopnia praca nauczyciela będzie wymagała ryzykowania w związku z wprowadzaniem np. nowych rozwiązań. Podejmowanie prób jest w tym zawodzie nie tylko codziennością, ale i wartością. Konieczne jest jednak eliminowanie ryzyka popełnienia błędu, m.in. poprzez wyposażenie nauczyciela, na etapie kształcenia czy doskonalenia zawodowego, w wiedzę i umiejętności dotyczące zaburzeń rozwojowych, umiejętności rozpoznawania symptomów, diagnozowania potrzeb, metod pracy i współpracy z grupą zróżnicowaną itp.

\section{Edukacja włączająca osób z niepełnosprawnością na etapie ponadgimnazjalnym}

Zgodnie z postanowieniami Konwencji: „Państwa Strony zapewniają, że osoby niepełnosprawne będą miały dostęp do powszechnego szkolnictwa wyższego, szkolenia zawodowego, kształcenia dorosłych i możliwości uczenia się przez całe życie, bez dyskryminacji i na zasadzie równości z innymi osobami. W tym celu Państwa Strony zagwarantują, że zapewnione będą racjonalne usprawnienia dla osób niepełnosprawnych" (art. 24 pkt 5, Konwencja... 2012, s. 13).

$\mathrm{Na}$ etapie kształcenia ponadgimnazjalnego uczeń ma do wyboru kilka rozwiązań: kształcenie w szkole średniej kończące się egzaminem maturalnym lub w zasadniczej szkole zawodowej. Zdecydowanie największa grupa uczniów z niepełnosprawnością wybiera zasadnicze szkoły zawodowe (ponad dwie trzecie). W roku szkolnym 2013/2014 nieco mniej niż 5 tys. uczniów podjęło edukację w szkołach przygotowujących do egzaminu maturalnego przy ponad 15 tys. uczestniczących w edukacji w zasadniczych szkołach zawodowych. W pierwszym przypadku zdecydowana większość, bo 73,45\%, młodzieży wybrała kształcenie w systemie włączającym, a tylko $26,55 \%$ w systemie kształcenia specjalnego. Odwrotnie niż w grupie

8 Art. 2. Europejskiej konwencji praw człowieka wskazuje: „Nikt nie może być pozbawiony praw do nauki. Wykonując swoje funkcje w dziedzinie wychowania i nauczania, Państwo uznaje prawo rodziców do zapewnienia tego wychowania i nauczania zgodnie z ich własnymi przekonaniami religijnymi i filozoficznymi" (Europejska konwencja praw człowieka, s. 33). 
uczniów uczestniczących w kształceniu w zasadniczych szkołach zawodowych, gdzie jedynie 17,15\% uczniów uczęszczało do szkół ogólnodostępnych, a 82,85\% do specjalnych (Uczniowie i studenci niepetnosprawni...).

W przypadku kształcenia $\mathrm{w}$ formach umożliwiających przystąpienie do egzaminu maturalnego w edukacji włączającej najwięcej jest (proporcjonalnie do liczby osób uczestniczących w kształceniu na danym etapie i z danym rodzajem zaburzenia) uczniów z ASD, słabosłyszących, z niepełnosprawnością ruchową i słabowidzących. Najmniej z głębokim uszkodzeniem narządu słuchu i wzroku.

Rysunek 6. Rodzaj niepełnosprawności a udział w edukacji włączającej - liceum (opracowanie własne na podstawie: Uczniowie i studenci niepełnosprawni...)

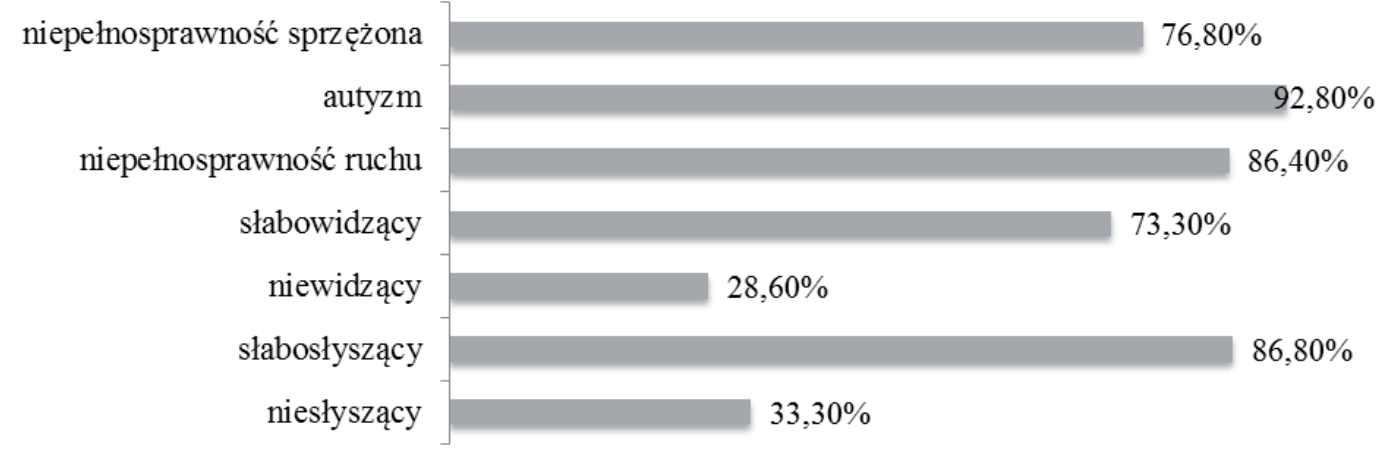

W sytuacji wyboru kształcenia zawodowego uczniowie z niepełnosprawnością zdecydowanie rzadziej wybierają jego ogólnodostępne formy.

Rysunek 7. Rodzaj niepełnosprawności a udział w edukacji włączającej - zasadnicza szkoła zawodowa (opracowanie własne na podstawie: Uczniowie i studenci niepetnosprawni...)

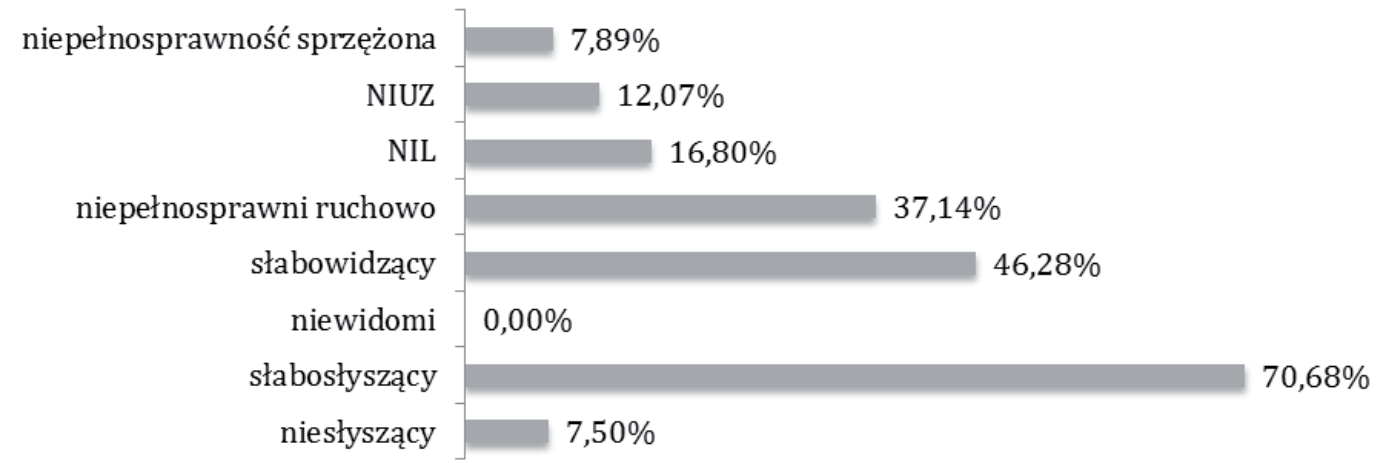


Najczęściej ma to miejsce w przypadku uczniów słabosłyszących, słabowidzących i z niepełnosprawnością narządu ruchu. W przypadku pozostałych grup wskaźniki udziału w edukacji włączającej sięgają zaledwie kilku, kilkunastu procent.

Mały udział uczniów z niepełnosprawnością w edukacji ponadgimnazjalnej kończącej się egzaminem maturalnym, umożliwiającym po jego zdaniu podjęcie nauki na poziomie wyższym, przekłada się bezpośrednio na wskaźniki zarówno podjęcia studiów wyższych, jak i uzyskania wyższego wykształcenia.

Kształcenie na poziomie wyższym w Polsce, podobnie jak w wielu innych krajach, nie uwzględnia podziału na uczelnie wyższe ogólnodostępne i specjalne (czyli przeznaczone dla osób z określonym rodzajem niepełnosprawności). Wymaga się więc od kandydata i studenta dostosowania do warunków kształcenia w jednym włączającym systemie. Jest to zdecydowanie łatwiejsze, jeśli uczeń już od początku uczestniczy w edukacji wspólnie ze sprawnymi rówieśnikami.

Tymczasem, jak pokazują zaprezentowane analizy, w Polsce mamy do czynienia z sytuacją systematycznego obniżania się wskaźników uczestnictwa w edukacji włączającej uczniów z niepełnosprawnością wraz z przechodzeniem na kolejne poziomy kształcenia.

Rysunek 8. Udział w edukacji włączającej w klasie zwykłej dzieci i młodzieży z niepełnosprawnością a etap kształcenia (opracowanie własne na podstawie: Uczniowie i studenci niepetnosprawni...; Udział w edukacji przedszkolnej dzieci z niepetnosprawnością a wykształcenie rodziców; Grzelak i in. 2014)

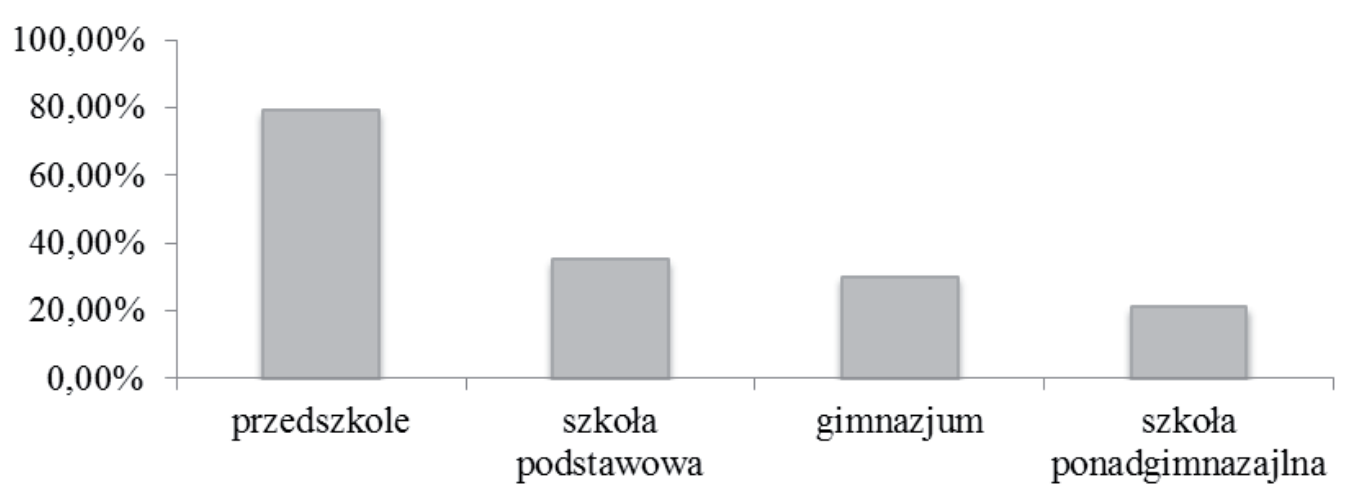

Podobnie sytuacja przedstawia się w przypadku kształcenia integracyjnego w rozumieniu rozporządzenia z 1993 r. Od szkoły podstawowej z każdym kolejnym etapem edukacji zmniejsza się grupa uczniów z niepełnosprawnością w szkołach/ klasach/oddziałach integracyjnych. Przyczyną obserwowanego stanu rzeczy może być wspomniana wcześniej niesatysfakcjonująca liczba placówek, w których taka forma kształcenia jest proponowana. Może być również tak, że złe doświadczenia społeczne (postawy odrzucenia lub izolowania przez grupę rówieśniczą) bądź niska jakość kształcenia (w wyniku braku lub nieskuteczności wsparcia ucznia w procesie 
kształcenia, które umożliwiłoby pokonywanie trudności edukacyjnych), objawiająca się niższymi kompetencjami uczniów z niepełnosprawnością, uniemożliwiają uczenie się wspólne ze sprawnymi rówieśnikami na kolejnych poziomach edukacji.

Ponownie przypomnieć należy o możliwej rezygnacji z kształcenia włączającego z powodów istniejących poza uczniem $\mathrm{z}$ niepełnosprawnością. Mogą nimi być np. braki kompetencyjne kadry pedagogicznej, zwłaszcza nauczycieli przedmiotów. W 2012 r. MNiSW ogłosiło standardy kształcenia nauczycieli ${ }^{9}$, obejmujące pięć modułów: (1) przygotowanie w zakresie merytorycznym do nauczania pierwszego przedmiotu (prowadzenia zajęć), (2) przygotowanie w zakresie psychologiczno-pedagogicznym, (3) przygotowanie w zakresie dydaktycznym, (4) przygotowanie do nauczania kolejnego przedmiotu (prowadzenia zajęć), (5) przygotowanie w zakresie pedagogiki specjalnej. Trzy pierwsze moduły są obligatoryjne, dwa ostatnie fakultatywne. Dodatkowo, jak można przeczytać w rozporządzeniu, „kształcenie w zakresie modułu 5. jest podejmowane przez studentów lub absolwentów studiów przygotowujących do wykonywania zawodu nauczyciela, którzy zamierzają uzyskać przygotowanie do nauczania określonego przedmiotu (prowadzenia zajęć) w przedszkolach, szkołach i placówkach specjalnych lub integracyjnych (oddziałach specjalnych lub integracyjnych)" (Rozporządzenie MNiSW 2012, s. 6). Z treści przytoczonego fragmentu wynika, że moduł piąty nie jest wymagany w przypadku kształcenia kadry dla szkół ogólnodostępnych. Oznaczać to może z pewnością mniejsze kompetencje lub brak kompetencji do pracy z uczniem z niepełnosprawnością i stać się powodem jego rezygnacji z kształcenia w szkole ogólnodostępnej.

W konsekwencji udział uczniów z niepełnosprawnością w edukacji specjalnej wzrasta wraz $\mathrm{z}$ przechodzeniem na kolejne poziomy kształcenia. Z etapu na etap w szkołach specjalnych kształci się coraz większa liczba uczniów $\mathrm{z}$ niepełnosprawnością.

9 Standardy kształcenia nauczycieli zostały przyjęte w Rozporzadzeniu MNiSW $z$ dn. 17 stycznia 2012 r. w sprawie standardów kształcenia przygotowującego do wykonywania zawodu nauczyciela. 
Rysunek 9. Udział w edukacji integracyjnej dzieci i młodzieży z niepełnosprawnością a etap kształcenia (opracowanie własne na podstawie: Uczniowie i studenci niepełnosprawni...; Udział w edukacji przedszkolnej dzieci z niepełnosprawnościa a wykształcenie rodziców; Grzelak i in. 2014)

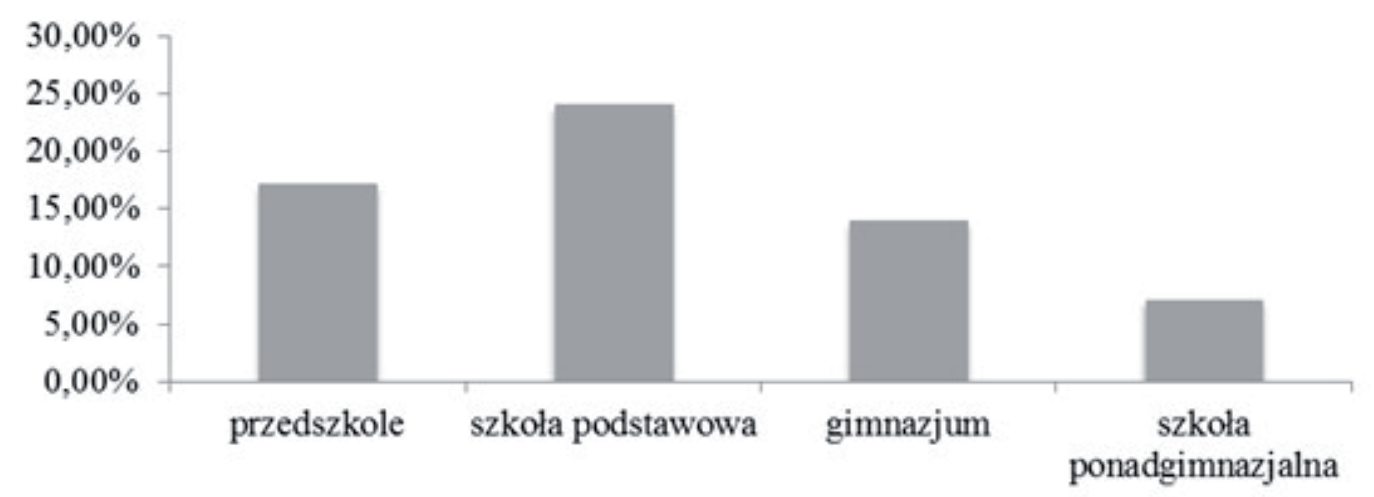

Można zatem wnioskować, że obecnie nie zostały w Polsce stworzone warunki sprzyjające pełnej integracji edukacyjnej. W kształceniu specjalnym na etapie przedszkolnym uczestniczy około 4-8\% dzieci (w zależności od źródła statystyki). W szkole podstawowej około 40\% uczniów z niepełnosprawnością realizuje obowiązek kształcenia w szkołach specjalnych.

Rysunek 10. Udział w edukacji specjalnej dzieci i młodzieży z niepełnosprawnością a etap kształcenia (opracowanie własne na podstawie: Uczniowie i studenci niepełnosprawni...; Udział w edukacji przedszkolnej dzieci z niepełnosprawnościa a wykształcenie rodziców; Grzelak i in. 2014; Chrzanowska 2015)

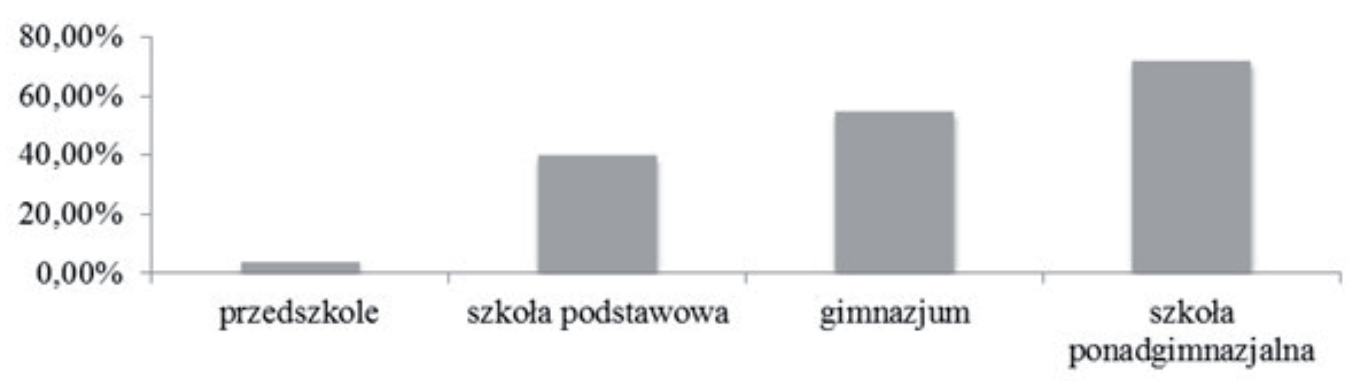

Na etapie gimnazjum wskaźnik wzrasta do 55\% (Chrzanowska 2015, s. 569), a w przypadku kształcenia ponadgimnazjalnego sięga blisko 70\%.

Analizy pokazują jednak, że w przypadku kształcenia włączającego można zaobserwować pewne optymistyczne tendencje. Dotyczą one uczniów z ASD, z niepełnosprawnością narządu ruchu czy lżejszymi stopniami uszkodzenia słuchu i wzroku. 
Rysunek 11. Uczeń z niepełnosprawnością w edukacji włączającej a etap kształcenia (opracowanie własne na podstawie: Uczniowie i studenci niepełnosprawni...)

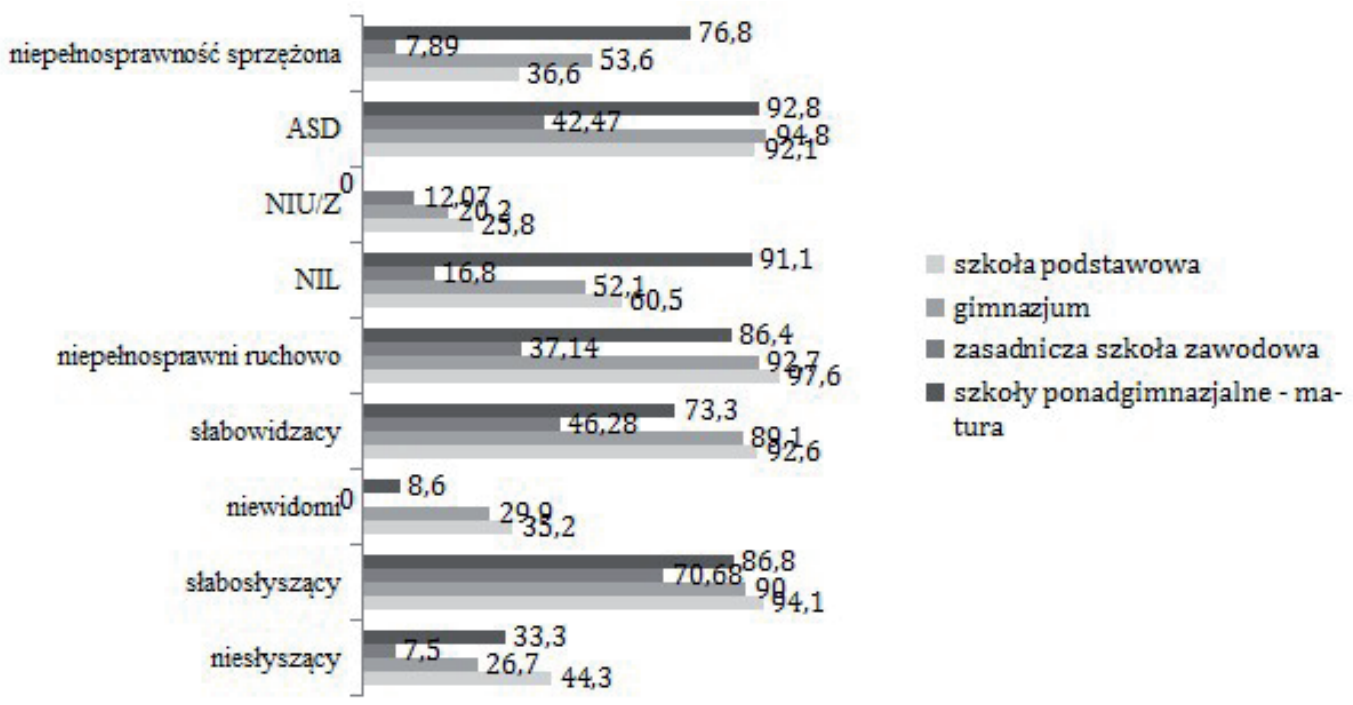

Pokazują one, że przez cały okres kształcenia ${ }^{10}$ uczą się oni w zasadzie wspólnie ze sprawnymi rówieśnikami.

\section{Bariery edukacji włączającej - wnioski z analiz dotyczących realiów kształcenia włączającego uczniów z niepełnosprawnością w Polsce}

Problematyka barier pojawiła się już wcześniej, w uzasadnieniach wyników prezentowanych analiz. Na zakończenie warto jednak poświęcić im jeszcze kilka zdań, odnosząc się również do kwestii dotąd nieporuszonych. Ich zidentyfikowanie stanowi w pewnym sensie podsumowanie prowadzonych analiz i może stać się wskazówką dla działań edukacyjnych wobec uczniów z niepełnosprawnością, mających na celu realizację idei kształcenia włączającego. Uświadamia też, na czym należy się skoncentrować, jeśli postanowienia i zapisy zawarte w Konwencji o prawach osób niepetnosprawnych mają w możliwie bliskiej perspektywie zostać w Polsce zrealizowane.

Autorzy Raportu IBE Właczajacy system edukacji i rynku pracy - rekomendacje dla polityki społecznej (Sochańska-Kawiecka i in. 2015, s. 26-27) definiują główne bariery: horyzontalne - odnoszące się do różnych sfer życia osób z niepełnosprawnością, oraz kierunkowe - które mogą utrudniać włączanie osób z niepełnosprawnością w obszary edukacji oraz rynku pracy. Do grupy pierwszej zaliczono bariery związane ze świadomością społeczną i systemem orzecznictwa, a do drugiej z edukacją i rynkiem pracy.

10 Pomijając etap edukacji na studiach wyższych, gdyż w tym tekście nie był on poddany analizom. 
Bariery horyzontalne związane ze świadomością społeczną odnoszą się głównie do społecznego postrzegania niepełnosprawności i negatywnego wizerunku osób z niepełnosprawnością. W dalszym ciągu dość powszechne jest myślenie o nich jako wykluczonych z głównego nurtu życia społecznego oraz przekonanie o konieczności objęcia ich specjalnym systemem w edukacji czy na rynku pracy. I w jednym, i drugim przypadku uznaje się, że jest to najskuteczniejsze i jednocześnie najlepsze rozwiązanie dla osób z niepełnosprawnością. Stąd przeświadczenie o konieczności utrzymania szkół specjalnych i zakładów pracy chronionej. Bariery związane z systemem orzecznictwa odnoszą się przede wszystkim do istnienia kilku rodzajów orzecznictwa: jednego do diagnozowania potrzeb związanych z edukacją dzieci i młodzieży (realizowanego przez publiczne poradnie psychologiczno-pedagogiczne i poradnie specjalistyczne) i innego, przeznaczonego dla osób dorosłych (np. orzecznictwo rentowe - ZUS, pozarentowe - powiatowe zespoły orzekania o niepełnosprawności) (Sochańska-Kawiecka i in. 2015, s. 26).

Bariery kierunkowe związane z edukacją zostały przez autorów wspomnianego raportu zdefiniowane jako wynikające z: kompetencji i postaw kadry pedagogicznej ${ }^{11}$; systemu finansowania nauki uczniów ze specjalnymi potrzebami edukacyjnymi; poziomu dostosowania procesu kształcenia do potrzeb specjalnych uczniów z niepełnosprawnością; postaw uczniów sprawnych i ich rodziców wobec osób z niepełnosprawnością jako uczestników wspólnego procesu kształcenia. Bariery kierunkowe związane z rynkiem pracy dotyczą z kolei: dostępu do otwartego rynku pracy; niskiej motywacji osób z niepełnosprawnością do podejmowania zatrudnienia; niewielkiej wiedzy pracodawców i samych osób z niepełnosprawnością na temat instrumentów wsparcia aktywizacji zawodowej osób z niepełnosprawnością czy dofinansowania ich wynagrodzeń; efektywności działania urzędów pracy w stosunku do osób z niepełnosprawnością (Sochańska-Kawiecka i in. 2015, s. 27-28).

Oprócz tego autorzy raportu sygnalizują możliwość pojawienia się barier związanych $\mathrm{z}$ rodzinami osób $\mathrm{z}$ niepełnosprawnością. Podnoszona jest głównie kwestia postaw rodzicielskich, często nadopiekuńczych, i braku wiary w możliwości osoby z niepełnosprawnością, co hamuje proces usamodzielniania się (Sochańska-Kawiecka i in. 2015, s. 29). Do problemu rodzin osób z niepełnosprawnością można i należy podejść znacznie szerzej i wskazać choćby na brak lub nieskuteczność wsparcia rodziny. Kwestię tę trzeba traktować bardzo szeroko, jako wsparcie psychologiczne, ale również instrumentalne (w tym finansowe), dzięki któremu możliwe jest choćby wypełnianie przez rodziców osób z niepełnosprawnością przysługujących im ról społeczno-kulturowych czy zawodowych.

$\mathrm{Na}$ podstawie przeprowadzonych analiz dostępu do edukacji włączającej można stwierdzić, że z pewnością jedną z podstawowych barier jest rodzaj

${ }^{11}$ Dotyczy to m.in. nastawienia nauczycieli do edukacji włączającej. Jak wynika z badań NIK z 2012 r., trzy czwarte nauczycieli prezentuje pogląd, że dzieci z niepełnosprawnością powinny się uczyć w szkołach specjalnych (Kształcenie uczniów... 2012, s. 55). 
niepełnosprawności. Analizy ujawniają, że o ile w przypadku niepełnosprawności nieodnoszących się bezpośrednio do kompetencji intelektualnych edukacja wspólna staje się dla ucznia coraz bardziej realna, o tyle w przypadku niepełnosprawności intelektualnej wciąż zdecydowana większość dzieci i młodzieży nie bierze w niej udziału. Osoby z niepełnosprawnością intelektualną są grupą najbardziej narażoną na wykluczenie nie tylko $\mathrm{z}$ edukacji ogólnodostępnej, ale również $\mathrm{z}$ otwartego rynku pracy (Sochańska-Kawiecka i in. 2015, s. 29).

Innym problemem jest odnalezienie się osoby z niepełnosprawnością w szkole ogólnodostępnej w kontekście priorytetów, na które współczesna polska szkoła jest nastawiona. Niemal nieprzerwanie w dyskusjach o systemie edukacji w Polsce przewija się temat jakości kształcenia. Opinie wyraźnie dychotomizują tu nie tylko społeczeństwo, ale również badaczy zjawiska. Stąd z ostrożnością i dużą dozą refleksji należy się odnosić do stwierdzenia, że współczesna polska szkoła ma się świetnie, a polscy uczniowie są jednymi z najlepiej wykształconych na świecie.

Od piętnastu lat w polskich szkołach realizowany jest system zewnętrznego egzaminowania. Jego wprowadzenie miało w założeniu przyczynić się do podniesienia jakości pracy szkół, a tym samym poziomu osiągnięć uczniów. Czy tak się stało, trudno jednoznacznie odpowiedzieć. Jednym ze źródeł, w których można znaleźć analizę poziomu osiągnięć polskich uczniów, są międzynarodowe badania OECD PISA. Polscy piętnastolatkowie biorą w nich udział już od kilku edycji12 Uzyskiwane przez nich wyniki są w zasadzie porównywalne. Dopiero ostatnia edycja, z 2012 r., pozwala wysnuć wniosek, że są one istotnie wyższe niż w latach poprzednich. Niektórzy badacze uważają, że świadczy to o sukcesie polskich reform systemu oświaty. Oponenci z kolei wskazują, że współczesna polska szkoła uczy przede wszystkim rozwiązywania zadań testowych, stąd lepsze pozycje w rankingach międzynarodowych. Obawiają się jednocześnie, że tak ustanowione priorytety

12 Badania OECD PISA piętnastolatków realizowane są co 3 lata. Polska uczestniczy w nich od 2000 r. Wybieranych jest losowo ponad 4 tys. uczniów w skali kraju. Badanie koncentruje się na trzech obszarach kompetencji: czytaniu ze zrozumieniem i umiejętności interpretacji czytanego tekstu, umiejętnościach matematycznych i rozumowaniu w naukach przyrodniczych. Polscy uczniowie w roku 2000 uzyskali w I kompetencji 479 pkt przy średniej w OECD 500 pkt, W 2003 r. - 497 przy średniej 494, w 2006 r. - 508 przy średniej 492, w 2009 r. - 500 przy średniej 494 i w 2012 r. - 518 przy średniej 496. W II kompetencji otrzymali w 2003 r. - 490 pkt przy średniej 500, w 2006 r. - 495 przy średniej 498, w 2009 r. - 495 przy średniej 496 i w 2012 r. - 518 przy średniej 494. W III kompetencji w 2006 r. dostali 498 pkt przy średniej 500, w 2009 r. 508 przy średniej 501 i w 2012 r. - 526 przy średniej 501. Warto jednak zaznaczyć, że w badaniu w 2000 r. uczestniczyło 37 krajów, w 2003 r. - 40, w 2006 r. - 57, w 2009 r. - 65, w 2012 r. - 65. Jak można zauważyć, zmiana liczby krajów biorących udział w badaniach miała w przypadku I kompetencji wpływ na obniżenie średniego wyniku dla całego regionu OECD. Do 2009 r. różnice w wynikach polskich uczniów były na tyle nieduże, że nie można było ich uznać za istotne statystycznie. Dopiero wskaźniki z ostatniej serii badań upoważniają do takiego wniosku (źródło: www.archiwum.men.gov.pl; www.biblioteka-krk.ibe.edu.pl). 
promują w istocie rywalizację i mogą się stać, czy też się stają, powodem psychologicznych problemów dzieci i młodzieży o niespotykanej dotąd skali.

W Polsce informacje na temat rozpowszechnienia w populacji dzieci i młodzieży zaburzeń psychicznych są fragmentaryczne i niepełne (Tabak 2014). Nie istnieją całościowe badania epidemiologiczne, określające rozpowszechnienie zaburzeń psychicznych wśród dzieci i młodzieży (Namysłowska 2013, s. 4-9). Przytaczane przez Izabelę Tabak dane z najnowszej serii międzynarodowych badań ankietowych nad zachowaniami zdrowotnymi młodzieży szkolnej HBSC (Health Behaviour in School-aged Children. WHO Collaborative Study) z 2010 r., prowadzonych przez Barbarę Woynarowską i Joannę Mazur (Mazur, Woynarowska 2012), wskazują, że u znacznej części dzieci i młodzieży w Polsce pojawiają się narastające wraz z wiekiem zaburzenia psychosomatyczne, takie jak np. bóle głowy (od 7\% u 11-latków do $17 \%$ u 17-latków), bóle pleców (od 5 do 8,5\%), przygnębienie (od 6 do 9\%), zdenerwowanie (od 14 do 16\%). Co najmniej dwie dolegliwości subiektywne odczuwało prawie codziennie lub częściej niż raz w tygodniu około 40\% młodzieży. Małe zadowolenie z życia stwierdzono z kolei u 15\% 11-latków, 21,5\% 13-latków, 25\% 15-latków i aż 27,7\% 17-latków. Jest to grupa dzieci i młodzieży szczególnie zagrożona zaburzeniami zdrowia psychicznego, głównie depresją. Analizy tendencji zmian w czasie prowadzone przez polski zespół HBSC wskazują, że w latach 1994-2010 we wszystkich badanych grupach wiekowych $(11,13,15$ lat) nasiliły się bóle brzucha i bóle pleców, a wśród 13- i 15-latków również bóle i zawroty głowy (Tabak 2014, s. 120-121). Jak zauważa Izabela Tabak, odsetek młodzieży przyjmującej środki uspokajające bez wskazań lekarskich jest w Polsce od kilku lat najwyższy w Europie (w 2011 r. - 15\% przy średniej europejskiej 6\%).

W tym kontekście pojawia się pytanie: czy i jak problem ten przedstawia się w grupie uczniów z niepełnosprawnością? Niestety, nie ma w Polsce badań, które podejmowałyby analizy w tym zakresie. Domyślać się można, że stres związany z udziałem w edukacji, zwłaszcza w kontekście planów życiowych i możliwości korzystania z otwartego rynku pracy młodych ludzi z niepełnosprawnością, jest nie mniejszy niż w populacji ogólnej, jeśli nie znacznie większy.

Kolejna z barier edukacji włączającej dzieci i młodzieży z niepełnosprawnością w Polsce wiąże się ze stopniem zaburzenia. Jak wskazały przeprowadzone analizy, im cięższy stopień niepełnosprawności, tym mniej uczniów w edukacji włączającej na każdym $z$ etapów kształcenia. Potwierdza to jedynie zasygnalizowane już wcześniej problemy dotyczące kompetencji kadry pedagogicznej, organizacji procesu kształcenia, barier architektonicznych. Nie ma wątpliwości, że w Polsce w stosunku do osób z głębszą (umiarkowaną i znaczną) oraz głęboką niepełnosprawnością trudno mówić o edukacji włączającej.

Inną barierą okazuje się wiek ucznia. Analizy pokazują zmniejszającą się liczbę uczniów z niepełnosprawnością w edukacji włączającej wraz z przechodzeniem na kolejne poziomy kształcenia. Na etapie szkoły podstawowej 36,4\% uczniów zmieniło szkołę ogólnodostępną na inną formę nauki, ponieważ nie radziło sobie z powodu 
swojej niepełnosprawności. Kolejne 10,2\% zostało przeniesione ze względu na wyniki w nauce (Sochańska-Kawiecka i in. 2015, s. 62). Na etapie gimnazjum wskaźniki są jeszcze wyższe, odpowiednio: 40 i 20\% (tamże, s. 66). Jedną z przyczyn takiego stanu rzeczy może być np. mało elastyczne podejście do programu nauczania w szkołach ogólnodostępnych (mimo istnienia prawnych możliwości jego dostosowania). Sztywne ramy narzucane nauczycielom w kwestii realizacji programu utrudniają dopasowanie kształcenia do potrzeb uczniów z niepełnosprawnością. Dotyczy to również sprawdzianów i egzaminów zewnętrznych. Dostosowanie to jest prawnie zagwarantowane (Komunikat dyrektora Centralnej Komisji Egzaminacyjnej...), niemniej nauczyciele mają trudności z jego realizacją, zwłaszcza w sytuacji np. zaburzeń sprzężonych czy głębszych stopni niepełnosprawności.

Nie ma również wątpliwości, że każda z grup osób z niepełnosprawnością będzie borykała się ze specyficznymi dla niej barierami, wynikającymi z występującego deficytu. W przypadku osób niesłyszących czy niewidzących z zaburzeniami neurologicznymi będą nimi np. problemy komunikacyjne, dla niepełnosprawnych ruchowo czy niewidzących - przeszkody architektoniczne. Dla wszystkich grup osób z niepełnosprawnością istotne są bariery związane ze stereotypami, negatywnym wizerunkiem, lękiem, obawą i niewiedzą na temat możliwości i potrzeb osób z niepełnosprawnością, brakiem wyobraźni i otwartości.

Jedne z nich można wyeliminować stosunkowo łatwo, inne będą wymagały czasu, ale czasu aktywnie wykorzystanego m.in. na społeczne kampanie, podejmowanie prób edukowania przez współuczestnictwo, pozytywne doświadczenia własne.

\section{Bibliografia}

Chrzanowska I. (2015). Edukacja włączająca na etapie przedszkolnym w Polsce fakty i refleksje dla przyszłych działań. „Studia Edukacyjne”, nr 37.

Chrzanowska I. (2015). Pedagogika specjalna. Od tradycji do współczesności. Kraków: Oficyna Wydawnicza Impuls.

Europejska konwencja praw człowieka (po nowelizacji przez protokół nr 11 i 14 z protokołem nr 1 oraz protokołami nr 4, 6, 7, 12 i 13), Europejski Trybunał Praw Człowieka Council of Europe, Strasbourg, www.conventions.coe.int (otwarty 15.11.2015).

Falkowska E., Telusiewicz-Pacak A. (red.). (2013). Dzieci w Polsce. Dane, liczby, statystyki. Warszawa: Polski Komitet Narodowy UNICEF.

Grzelak P., Kubicki P., Orłowska M. (2014). Realizacja badania ścieżek edukacyjnych niepetnosprawnych dzieci, uczniów i absolwentów. Raport końcowy. Warszawa: IBE.

Komunikat dyrektora Centralnej Komisji Egzaminacyjnej z 30 sierpnia 2013 r.w sprawie sposobów dostosowania warunków i form przeprowadzania $w$ roku szkolnym 2013/2014 egzaminu maturalnego do potrzeb absolwentów ze specjalnymi 
potrzebami edukacyjnymi, w tym niepetnosprawnych, niedostosowanych społecznie oraz zagrożonych niedostosowaniem społecznym, www.komisja.pl/pobierz/ matura/2014/dostosowania_m_2014.pdf (otwarty 27.11.2015).

Konwencja o prawach osób niepełnosprawnych, Dz.U. RP z dn. 25 października 2012 r., poz. 1169.

Kształcenie uczniów z niepełnosprawnościami o specjalnych potrzebach edukacyjnych (2012). Warszawa: NIK.

Mazur J., Woynarowska B. (red.). (2012). Tendencje zmian zachowań zdrowotnych i wybranych wskaźników zdrowia młodzieży szkolnej w latach 1990-2010. Warszawa: Instytut Matki i Dziecka, Wydział Pedagogiczny UW.

Namysłowska I. (2013). Zdrowie psychiczne dzieci i młodzieży w Polsce - stan rozwoju opieki psychicznej i zadania na przyszłość. „Postępy Nauk Medycznych”, nr 1.

Pańczyk J. (2001). Pedagogika specjalna w Polsce u progu XXI wieku. W: Dykcik W. (red.). Pedagogika specjalna. Poznań: WN UAM.

Rozporządzenie MENiS z dn. 18 stycznia 2005 r. w sprawie warunków organizowania kształcenia, wychowania i opieki dzieci i młodzieży niepełnosprawnych oraz niedostosowanych społecznie w przedszkolach, szkołach i oddziałach ogólnodostępnych $i$ integracyjnych. Dz.U. nr 19, poz. 167.

Rozporządzenie MNiSW z dn. 17 stycznia 2012 r. w sprawie standardów kształcenia przygotowującego do wykonywania zawodu nauczyciela. Dz.U. RP z dn. 6 lutego 2012 r., poz. 131.

Sochańska-Kawiecka M., Makowska-Belta E., Milczarek D., Morysińska A., Zielińska D. A. (2015). Właczający system edukacji i rynku pracy - rekomendacje dla polityki publicznej. Raport końcowy. Warszawa: IBE.

Tabak I. (2014). Zdrowie psychiczne dzieci i młodzieży. Wsparcie dzieci i młodzieży w pokonywaniu problemów. „Studia BAS”, nr 2 (38), s. 113-138, www.bas.gov.pl. Uczniowie i studenci niepełnosprawni, Biuro Pełnomocnika Rządu ds. Osób Niepełnosprawnych, niepelnosprawni.gov.pl (otwarty 23.11.2015).

www.archiwum.men.gov.pl (otwarty 23.11.2015).

www.biblioteka-krk.ibe.edu.pl (otwarty 23.11.2015).

Zarządzenie nr 29 MEN z dn. 4 października 1993 r. w sprawie zasad organizowania opieki nad uczniami niepetnosprawnymi, ich kształcenia $w$ ogólnodostępnych i integracyjnych publicznych przedszkolach, szkołach i placówkach organizacji kształcenia specjalnego. Dz. Urz. MEN, nr 9, poz. 36. 


\title{
CHILDREN AND YOUTH WITH DISABILLITIES IN INCLUSIVE EDUCATION IN POLAND - CURRENT SITUATION AND DIMENSION
}

\begin{abstract}
Inclusion of people with disabilities is a modern trend of education in Poland. In 2012. Poland ratified the Convention on the Rights of Persons with Disabilities. Text attempt to analyze the state of implementation of ideas for all stages of compulsory education. It is also an attempt to diagnose the main barriers to the implementation of the plans.
\end{abstract}

Key words: Inclusive education, disability, barriers

Iwona Chrzanowska - profesor doktor habilitowana, profesor zwyczajna Uniwersytetu im. Adama Mickiewicza w Poznaniu, Społecznej Akademii Nauk w Łodzi. Autorka monografii, m.in.: Pedagogika specjalna. Od tradycji do współczesności (2015), Zaniedbane obszary edukacji - pomiędzy pedagogika a pedagogika specjalną. Wybrane zagadnienia (2009), Problemy edukacji dzieci i młodzieży z niepetnosprawnością. Regionalna specyfika czy ogólnopolska tendencja (2010). Adres e-mail: chrzanowska.iwona1@gmail.com. 